\title{
Editorial: How European venture capital functions as an asset class for pensions
}

The precise extent to which the UK pension industry is underfunded remains shrouded in mystery, largely due to the number of different and conflicting measures that are used to measure it. UBS Warburg has estimated that the FRS 17 deficit for FTSE 100 companies is $£, 56.4$ billion, while Lane Clark \& Peacock claim the figure should be $\mathcal{2} 42$ billion. ${ }^{1}$ This would imply that UK corporate pension plans are anything up to 15.5 per cent underfunded assuming total plan assets of $£ 362$ billion. $^{2}$ In September 2004 Watson Wyatt estimated that the current public sector pension deficit could be as high as $£ 580$ billion (officially estimated at $£ 380$ billion back in March 2002). ${ }^{3}$ This suggests that the average local authority pension fund could be at least 50 per cent underfunded, a worrying prospect not only for Local Authority employees, but also for anyone who pays council tax in the UK. Last year 20 per cent of a total of $£ 14$ billion raised from UK council tax was used for pension fund contributions, and this year, the figure is expected to increase by at least $\mathcal{E}^{300}$ million. $^{4}$

Yet a recent UK pension industry study for $2004^{5}$ shows that the average corporate plan is 99 per cent funded and the average local authority plan is 90 per cent funded. How can any observer make sense of these apparently irreconcilable conclusions? The answer, as Professor Joad used to say, is 'it all depends what you mean by ...' The 99 per cent and 90 per cent figures given above are solvency ratios, that is the net present value of plan assets divided by the net present value of anticipated liabilities. The now largely discredited minimum funding requirement (MFR) applies a similar approach. The problem with all such measures is that they can be manipulated to give almost any required answer. The calculation of a net present value for plan assets rather than taking the actual present value allows a flattering future value to be arrived at by favourable assumptions of future investment performance. The calculation of a net present value for future liabilities requires the assumption of a discount factor, and a difference of a few percentage points one way or the other will produce widely divergent results when calculated over a long period. Finally, an estimation of future liabilities is heavily dependent on assumptions of longevity expectations (which have changed significantly in recent years), future retirement ages and levels of contributions.

Whatever the case, there is general agreement that the UK pension industry has been visited with an unprecedented funding crisis; witness the large number of final salary schemes which have been closed in recent years. Ironically, however, while the various measures used to estimate this serve only to obfuscate the actual amounts involved, at the same time they do point the way to both how and why the actual deficit arose in the first 
place - not a question which the UK pension industry has been very keen to pose.

In my own specialist area of venture capital partnerships, practitioners in Europe look to the USA to learn how the acknowledged world leaders in the field go about planning and executing their investment strategy. Sadly, UK pension funds have not followed suit and nowhere is this better illustrated than in the area of asset allocation, which can throw up some very striking differences when compared to best practice in the USA. In order fully to understand this point, however, it is necessary first to touch upon something as fundamental as the difference between simple and compound interest to illustrate the muddled thinking which has permeated the industry in this regard here in the UK.

\section{The difference between compound and annual returns - the need for a compound returns mindset}

Of course, the difference between simple and compound interest is being used as an analogy, but it is an apposite one. For what is being referred to is the difference between annual investment returns and compound investment returns over a period, which is essentially the same as the difference between simple and compound interest. Surprisingly, both UK pension trustees and those who advise them have had great difficulty in grasping this difference, to the extent that the returns earned by some asset classes, venture capital being a good example, have been quite simply both inaccurately and inappropriately analysed when compared to, say, quoted equities or fixed interest securities.

Just as this misunderstanding clouds judgment on asset allocation decisions, so too does it muddle thinking on future funding requirements. For example, rather than discounting future liabilities to arrive at a net present value, the author would argue that it makes much more sense to model the actual anticipated future liabilities as and when they occur and then calculate what rate of return has to be earned by the actual present value of the pension fund over the intervening period in order to at least match these. It is here that the lack of understanding of the effect of a compound return over a period of time is seen perhaps to greatest disadvantage. If one is concerned with a period of many years, then how can it possibly be relevant to consider annual returns, unless one is endowed with omniscience and able to predict exactly what annual return each individual asset class is going to earn in each individual year? To complicate matters further, there are certain asset classes, venture capital again being a good example, for which the annual returns are simply not capable of being analysed on any meaningful basis, and yet which are ideal for the calculation of compound returns over time. This Editorial will attempt to explain why this is, and then circle back to consider how this impacts upon our consideration of pension fund asset allocation.

All venture capital partnerships suffer from something called 'the J curve'. Quite simply, because money is paid into them over a lengthy period, used for investment, and then distributed once investments are realised, the cumulative internal rate of return (IRR) of the fund will be heavily negative in the early years, as outflows exceed inflows, and then steadily improve over the life of the fund. Thus, any attempt to measure the annual return of a venture partnership would be hostage to which particular year of the fund was chosen; the best venture fund in the world would show an appalling performance in, say, year two, and could still be difficult to distinguish from a bad 
fund in, say, year five. It is for this reason that venture returns, and indeed all private equity returns, are measured on a 'vintage year' basis showing the IRR to date of the fund starting from the year in which it was formed. Thus, a 1991 performance figure of 16 per cent for the FTSE index means that the index increased by 16 per cent during the calendar year 1991, but says nothing at all about what its performance might have been for any other period. A 1991 performance figure of 16 per cent for a venture capital partnership means that it has a compound return of 16 per cent for the period from 1991 , or to put it another way, that it notionally achieved not just 16 per cent for 1991, but also 16 per cent compound for every year since then - clearly a very different matter and a much more attractive return.

Sadly, this difference has not been understood well or indeed at all within the pensions community and there have been many examples of people attempting to make direct comparisons between venture and quoted returns without realising that they are dealing with apples and oranges. The answer is of course to change the oranges into apples by restating the quoted figures onto a vintage year basis, after which direct comparisons may validly be made. This exercise throws up what to some in the industry are very startling results. It transpires that, for every year during the nineties bar one, European upper quartile venture significantly out-performed quoted equities. For example, $£ 10$ invested in the FTSE index in 1993 would have been worth $£^{21}$ twelve years later, whereas the same amount invested in upper quartile European venture would have grown to $\mathcal{1 0 3}$, and this is a typical example of the decade as a whole. Yet the UK pension industry even today has only about half a per cent of plan assets invested in private equity, and most funds have no allocation at all. Contrast this with the USA where most pension funds have had substantial allocations to venture for many years. The Yale endowment, for example, has been as high as 25 per cent and their ten-year compound return from venture is approximately 35 per cent. ${ }^{6}$

\section{The Yale Model - A multi- asset class approach to investment strategy}

Yale is actually an interesting example of just how different asset allocation thinking can be on the other side of the Atlantic. Rather than what the author thinks of as a nineteenth century asset mix of quoted equity and fixed interest (typical in the UK even today), they select five different asset classes, with as little correlation as possible between them, and split their portfolio more or less equally between them. Given this approach, a 20 per cent allocation to venture is almost inevitable, whereas in the UK it is usually between two per cent and nothing at all. The Yale approach has led to their endowment being among the top one per cent by investment performance, yet so far as this writer is aware not one single UK pension fund has attempted to reproduce it, nor are any of the pension consultants here advocating it.

Apart from an unthinking prejudice against European ventures as an asset class (a prejudice which is entirely unsupported by actual performance, as demonstrated above) the main reason for this difference of approach lies in the fact that in the USA, where a higher level of general financial sophistication prevails, the concept of compound returns over a long period is well understood; IRR is king. In the UK, by contrast, there is a fixation with the short term in general and annual returns in particular. In the USA, in consequence, there is a huge excess of demand, represented by institutional 
money, over supply, represented by the available capacity of high quality venture partnerships. A US pension fund investor recognises venture capital for the very attractive asset class that it is. The main concern will be gaining access to enough upper quartile partnerships to satisfy their appetite.

\section{How the funding deficit could have been avoided}

My speech to the NAPF investment conference in Edinburgh examined just what would have happened had British pension funds throughout the nineties had the same sort of levels of investment in venture as did their US counterparts. Suffice it to say that the difference would have been little short of dramatic, and sufficient that, certainly in the case of corporate pension plans, the present funding deficit would probably not have arisen. Thus the various final salary schemes that have been scrapped could in fact have been saved.

This makes depressing reading for UK workers contributing to occupational pension plans, since there can be no dispute that, compared with their US counterparts, UK pension trustees have made consistently and significantly wrong asset allocation decisions over the course of the last decade to the considerable detriment of their beneficiaries. It would be encouraging to report that there were signs that they are acknowledging their errors and adopting a new approach, but if anything, the opposite is the case - the author is certainly not aware of any proposals for anything like a 20 per cent allocation to private equity.

This Editorial has focused specifically on venture capital simply because it is the author's own area of specialty, and thus the asset class which he understands the best. The issue identified here, however, is general and wide ranging and raises some disturbing questions. Why is it that proven investment models which are freely available for study and discussion should be ignored? Why does the UK pension industry believe the Yale model would not work equally well here as it has in the USA? Why should they allow themselves to be influenced against an asset class by prejudicial hearsay evidence rather than examining the figures for themselves?

In my opinion, an opportunity has been missed with the recent Pensions Act to carry out a radical overhaul of the whole structure of the UK pension industry that could only have been for the benefit of beneficiaries at large. If pension trustees cannot be trusted to carry out asset allocation in a thorough and proper manner then it should be taken out of their hands altogether. For example, it could be performed centrally by government, by reference to the actuarial profile of each particular scheme, and with the resulting asset mixes being remitted back to them for the selection of individual managers. Or we could establish something in the spirit of the Swedish AP programme, taking 70 per cent of pension plan assets away into their control, leaving behind 30 per cent which the existing plans could happily invest in quoted securities. Whatever the case, surely some way must be found of ensuring that the mistakes of the past decade and a half will not be repeated.

\section{Guy Fraser-Sampson Managing Partner Mowbray Capital LLP}

\section{References}

1 Pensions World (2004), December.

2 Greenwich Associates (2004)

Pensions World (2004), September.

The Times (2005), 12 February.

See ref. 2 above.

6 Yale Endowment Annual Report (2003). 